\title{
GASIFICATION OF SOLID WASTE-POTENTIAL AND APPLICATION OF CO-CURRENT MOVING BED GASIFIERS
}

\author{
M. J. Groeneveld and W. P. M. van SwaalJ
}

Dept. of Chemical Engineering. Twente University of Technology, PO Box 217, 7500 AE Enschede, The Netherlands

\section{SUMMARY}

A review is given of gasification processes for solid fuels with special emphasis on waste gasification. Although the co-current moving bed gasifier has not been under consideration for a long time, it offers interesting possibilities for waste gasification. Some operational data are given.

Two potential applications are discussed-gasification of agricultural waste (maize cobs) in the rural areas of Tanzania and municipal waste gasification.

\section{INTRODUCTION}

The utilisation of solid waste as a fuel to generate heat or power is difficult because of its low caloric value and the tar and smoke production which accompanies combustion. One of the most promising possibilities for dealing with these problems is the production of a clean fuel gas from waste by gasification.

Gasification involves heating of the feedstock followed by reaction with air, oxygen, steam or various mixtures of these to produce a hydrogen-, carbonmonoxide- and methane-containing gas. Coal gasification is better known but is in principle no different. The gas from coal is, if necessary, desulphurised and can be applied for: (i) available and advanced power generating processes as a clean fuel gas; (ii) the preparation of pipeline gas; (iii) the preparation of hydrogen, ammonia, methanol and hydrocarbons and (iv) the steel industry as a reducing agent. A clean fuel gas from agricultural or forestry waste and domestic refuse has the same potential but is hardly ever produced.

Applied Energy 0306-2619/79/0005-0165/\$02-25 165 Applied Science Publishers Ltd, England, 1979 Printed in Great Britain 


\section{HISTORY OF GASIFICATION}

The oldest means of gas production from carbonaceous materials is dry distillation (i.e. heating of the feedstock in an oxygen-free atmosphere). Using this process principle, the first coal-gas company started in London in 1812 and produced light gas. ${ }^{1}$ A second method of gas production is the (cyclic) water-gas process, developed about 1880 and applied on an industrial scale from about $1900 .{ }^{2}$ Older still is the third method of continuous gasification with air. In 1839 Bischof designed a vertical shaft gasifier for coal and peat gasification (see Fig. 1) ${ }^{3}$ This type was improved for example by Siemens (1857) and used in Europe for more than a century. ${ }^{3}$ The main problems with these gasifiers were tar production and ash removal. According to Ebelman $(1840)^{2}$ tar production could be overcome by leading the product gas through a glowing coke bed. Based on this principle several gasifiers with one or two glowing zones were built - double shaft gasifiers (Fig. 2); double fire gasifiers (Fig. 3); gasifiers in which the pyrolysis products are injected under the grid (Fig. 4) and co-current gasifiers (Fig. 5).

During the period 1880 to 1920, especially in Germany, improved designs were made for the gasification of low-grade coals such as lignite and of vegetable materials. Other gasifiers have been designed to cope with the problem of ash removal, leading to the famous rotating grid type (first designed by Kerpely, $1904^{2}$ ). The powdered coal gasifier of Hirth and Maconnet (1905) was an early example of a new technique for eliminating ash removal problems as well as the problem of caking in a packed bed. This technique has led to the fluid bed gasifier (Winkler, 1926) and the entrained suspension gasifier (Schmalfeldt-Wintershall, 1940). During the second world war, small gasifiers were constructed for car and lorry traction because of the shortage of liquid hydrocarbons in continental Europe. Most used anthracite or charcoal as feedstock but some employed peat or wood blocks. While early gasifiers mainly operated at atmospheric pressure, during and after world war Il pressurised gasifiers were developed, e.g. based on the designs of Lurgi (1936) and of Koppers-Totzek (1948). ${ }^{3}$

Oil and natural gas took over the previously dominant position of coal with respect to energy supplies, however, and consequently the role of gas production was considerably reduced. Nevertheless, exceptions can be found in areas with special economic circumstances (in South Africa, parts of the USSR and in the developing countries).

The energy crisis renewed interest in the gasification of coal and other potential solid fuels and consequently, as well as the already well known gasifiers, new types are now under development. ${ }^{4.5}$ Especially in the USA, attention is being paid to the production of pipeline gas via hydrogen gasification (Higas). In addition, underground gasification is under renewed discussion for power generation ${ }^{5}$ and the first refuse gasifiers are in operation. ${ }^{6}$ 

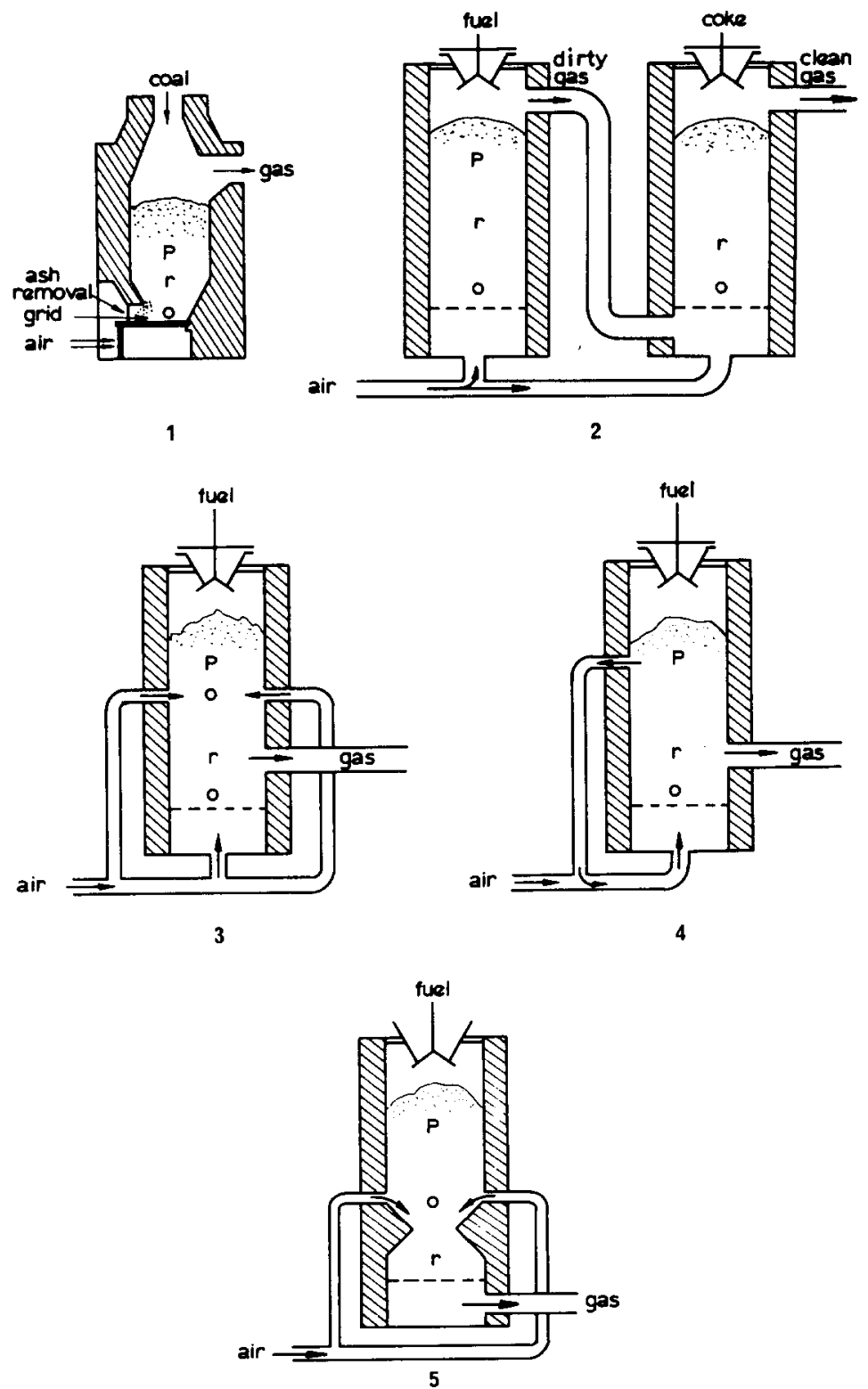

Figs. 1-5. 1. Counter-current gasifier (Bischoff (1839)); 2. Double-shaft gasifier; 3. Double-fire gasifier; 4. Gasifier with injection of the pyrolysis products; 5 . Co-current gasifier. (p: drying and pyrolysis zone; $r$ : reduction zone; $o$ : oxidation zone.) 


\section{GASIFICATION PROCESSES}

Gasification is a complex process during which the solid fuel successively dries, pyrolyses (organic gases and liquids are distilled off, consequently the solid residue achieves a higher carbon content) and reacts with $\mathrm{O}_{2}, \mathrm{H}_{2} \mathrm{O}, \mathrm{CO}_{2}$ and $\mathrm{H}_{2}$ in a complex manner, given below in a simplified form ((1) to (4)):

$$
\begin{aligned}
\mathrm{C}+\mathrm{O}_{2} & =\mathrm{CO}_{2}-394 \mathrm{~kJ} / \mathrm{kmol} \mathrm{C} \\
\mathrm{C}+\mathrm{CO}_{2} & =2 \mathrm{CO}+171 \mathrm{~kJ} / \mathrm{kmol} \mathrm{C} \\
\mathrm{C}+\mathrm{H}_{2} \mathrm{O} & =\mathrm{CO}+\mathrm{H}_{2}+130 \cdot 5 \mathrm{~kJ} / \mathrm{kmol} \mathrm{C} \\
\mathrm{C}+2 \mathrm{H}_{2} & =\mathrm{CH}_{4}-75 \mathrm{~kJ} / \mathrm{kmol} \mathrm{C}
\end{aligned}
$$

Gasification can be divided into autotherm and allotherm processes. Allotherm processes need an external heat source-for example, nuclear energy--and will not be discussed further here. Autotherm processes can be classified according to the heat of combustion of the product gas:

(i) Low BTU gas $\left(4000-5000 \mathrm{~kJ} / \mathrm{m}^{3}\right)$ for gasification with air and steam (partial oxidation).

(ii) Medium BTU gas $\left( \pm 10 \cdot 000 \mathrm{~kJ} / \mathrm{m}^{3}\right)$ for gasification with oxygen and steam (partial oxidation).

(iii) High BTU gas $\left( \pm 40.000 \mathrm{~kJ} / \mathrm{m}^{3}\right)$, or pipeline gas, for gasification with hydrogen (hydrogasification).

For waste gasification only the simple partial oxidation processes are attractive and these will be discussed in more detail. The most important gasification types are presented in Fig. 6, together with temperature and solid fuel conversion profiles. Typical results of these processes are shown in Table 1.

The liquid salt and multi-stage gasifiers, which are rather complex and not attractive for waste gasification, are not shown. The design of a gasification process is influenced by the properties of the feedstock and the following operational variables.

\section{Design aspects of partial oxidation gasifiers}

The design of the reactor for a gasification process is determined as described below.

Particle size: The particle size of the feedstock dominates the choice of reactor type. Particles larger than $\pm 2 \mathrm{~mm}$ can be gasified in a moving bed, particles between 0.1 and $20 \mathrm{~mm}$ are conveniently gasified in a fluid bed and particles smaller than $0.1 \mathrm{~mm}$ are suitable for gasification in an entrained suspension reactor. For waste gasification, the disadvantages of size reduction are its costs and increased tar production. Particles can also be agglomerated but apart from the additional cost this operation makes the overall process more complex. 


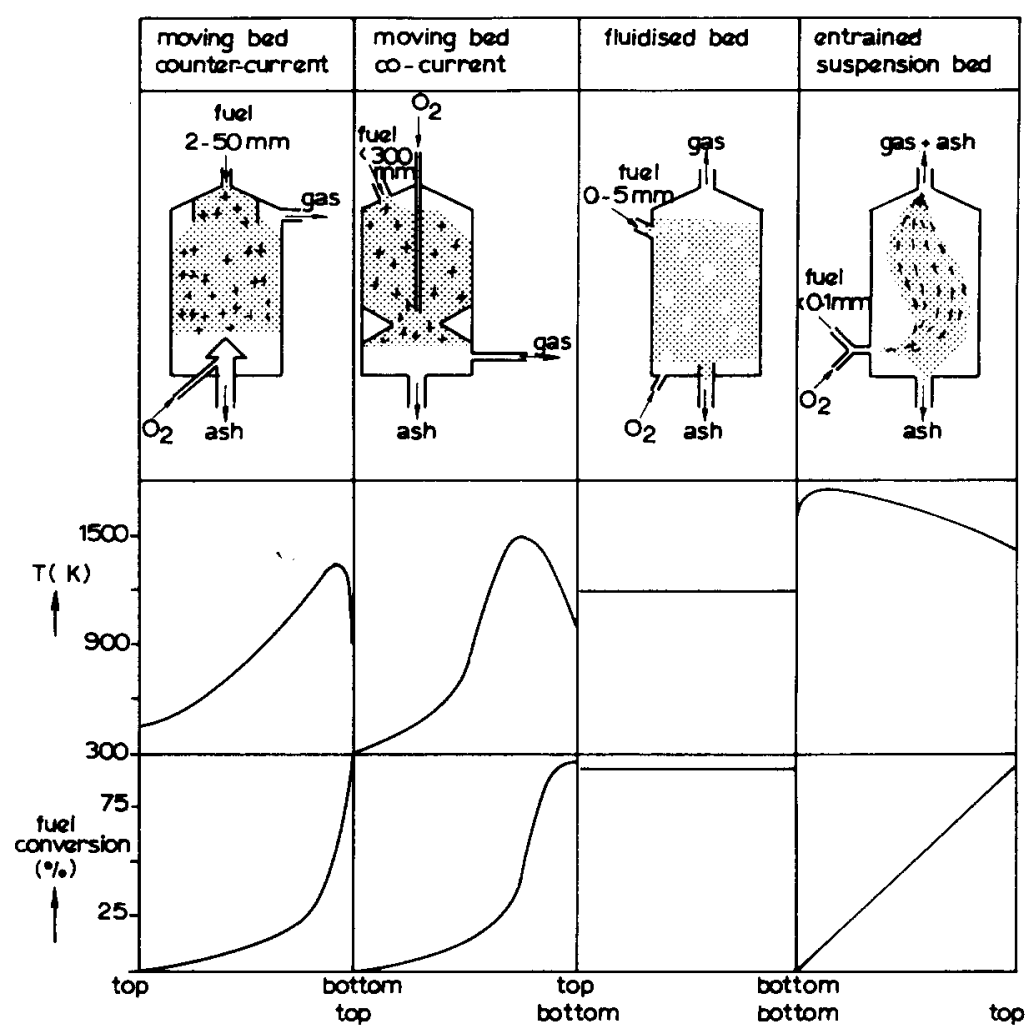

Fig. 6. Reactor types with corresponding temperature and conversion profiles.

Counter-current or co-current operation: The choice of mode of operation is of particular interest in packed-bed gasifiers because both ways are feasible. As can be seen in Fig. 6, the main difference in the mode of operation is that in the countercurrent process the products of the pyrolysis and drying zone are entrained with the product gas which therefore contains the tar components. In the co-current operation the pyrolysis products are passed through the hottest zone of the reactor (oxidation zone) where the tar is converted. The main advantages of counter-current operation are: (a) the high burn out of the charcoal and (b) the low exit temperature of the product gas because of the counter-current heat exchange with the feedstock. Disadvantages are entrained tar production and difficulties with the fuel intake. Solid fuel is introduced at a place where gas tightness is critical. The price of achieving the tar free product gas of the co-current operation is a higher outlet temperature $\left(700^{\circ} \mathrm{C}\right)$ in combination with a lower heat of combustion of the gas.

Ash removal: This can be accomplished as a liquid or a solid, depending on the 
TABLE 1

REACTOR TYPES WITH TYPICAL DATA FOR COAL AND WASTE GASIFICATION

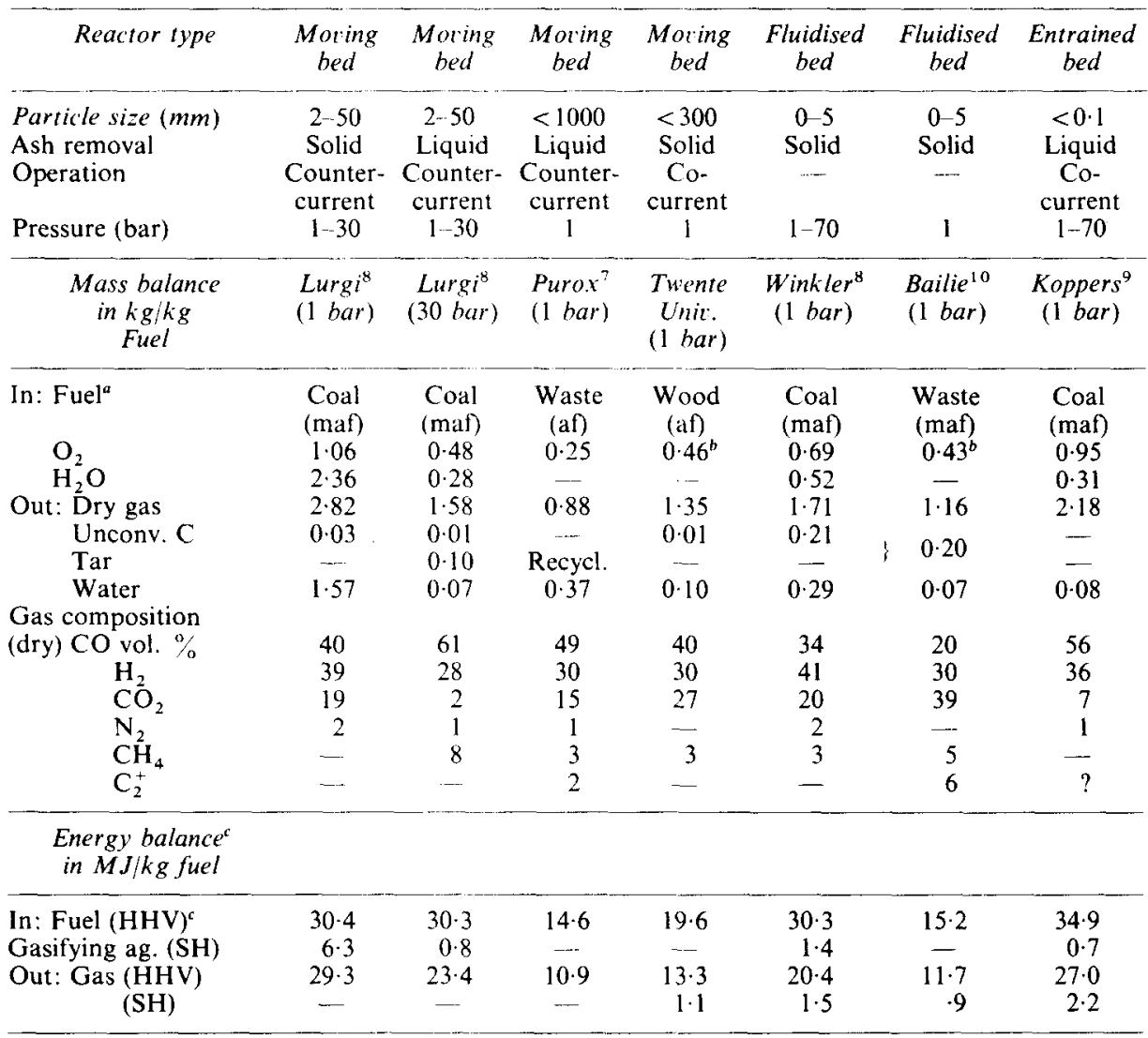

a m (moisture) a (ash) f (free)

${ }^{b}$ in air

${ }^{c} \mathrm{HHV}=$ higher heating value; $\mathrm{SH}=$ sensible heat.

temperature (melting point between 900 and $1100^{\circ} \mathrm{C}$, see Fig. 6). In the case of a fluid bed reactor the temperature can be controlled easily and kept below the melting point of the ash. The ash can then be removed as a solid. Entrained suspension beds are operated with short residence times ( $\sim$ a few seconds) and therefore at high temperatures (above $1500^{\circ} \mathrm{C}$ ). Ash can be removed as a liquid or, after quenching with water, as a solid. The situation is more complex in the counter-current, moving bed types. They can operate with or without a grid to separate the char bed and the ash and, depending on the gasifying agent, the ash can be removed as a liquid or as a solid. However, partial or local melting of the ash should be avoided. In the case of gasification with pre-heated air or oxygen and, if necessary, with small amounts of steam, the ash will melt and in other cases the ash can be kept in the solid state (see 
Table 1). An advantage of liquid ash removal is that, after quenching in water, the solid residue can be disposed of easily due to its favourable leaching properties. Disadvantages are, however, the difficult operation of the process at low capacities and the more delicate start-up and shut-down procedures. As can be seen from the temperature profile in Fig. 6, ash removal in the co-current moving bed reactor will be in the solid state.

Pressure: For coal gasification, modern developments are aimed at high pressures (20-100 bar) for large scale production units because of: (a) the higher specific reactor capacity and (b) the higher methane content in the product gas. In the gasification of waste these advantages generally do not outweigh the more expensive gasifier construction. Usually the required capacity is still small in comparison with coal gasifiers.

Gasification agent and product gas composition: Typical examples of the different feedstocks, their gasification agents and their product gas composition are presented in Table 1. The composition is not solely a function of the gasifier type but also, of course, of the gasification agent (air, oxygen, steam, etc.) and the temperature of the inlet and outlet streams. The sensible heat of the product gas cannot always be recovered or recycled to the reactor. Therefore one should consider the gasification process as a whole (including all the process streams) when comparing process efficiencies.

\section{Evaluation of gasifier design for waste gasification processes}

Apart from the general design considerations given above, waste gasification has some additional demands. In comparison with coal gasification, the waste feedstock is generally less uniform in composition, especially with respect to domestic waste. Furthermore, the municipal solid waste refuse contains chlorine components which have to be removed from the gas during or after gasification.

As the required capacities range from small to intermediate $(5 \mathrm{~kg} / \mathrm{h}-10 \mathrm{ton} / \mathrm{h})$ the capital investment for both reactor and gas cleaning equipment should be low. In addition, operational costs, maintenance costs, etc., should be relatively low. Waste gasifiers should be robust and thus without fragile moving parts. If possible, feedstock preparation processes such as drying, separation, size reduction or agglomeration should be avoided.

Of the three types of gasifier--the moving bed, the fluid bed and the entrained suspension bed - the last two seem to be the least adequate for waste gasification according to these criteria. The fluid bed reactor is rather complex and usually requires a size reduction. It produces a product gas with a high tar content, demanding extensive gas cleaning. This is unnecessary if the gas is directly combusted in the disengaging zone. The entrained suspension bed gasifier needs a still smaller particle size but produces a more or less tar-free product gas at a high temperature. For the relatively small scale of waste gasification, this process will be too expensive.

The moving bed counter-current gasifier with solid-ash removal produces a tar- 
containing gas and may involve difficulties with ash removal depending on the ash content of the feedstock and the ash properties. The problem of ash removal is less severe in the liquid ash removal moving bed gasifiers but they are known to be more difficult to operate. If the gas is directly combusted, the high tar content can be accepted. In other cases a more or less tar-free gas should be produced. This can be done in counter-current gasifiers with special features as seen in Figs. 2, 3 and 4 but these types of gasifier have more control problems. For waste gasification some of these types appear quite promising and deserve further investigation. The cocurrent moving bed gasifier is simple to construct and to control, and produces a tarfree gas at a higher exit temperature. It has been successfully used for the gasification of vegetable materials. ${ }^{10.11}$ This process is especially suited for small-scale processing of vegetable materials because it requires relatively little treatment of the product gases. For combustion, except for dust removal, no treatment is necessary. In addition, gas turbines can run directly on the product gas and after dust removal and cooling the gas is suitable for internal combustion engines.

A second application of the co-current moving bed reactor could be for refuse gasification or with other feedstocks containing chlorine components such as PVC. In a co-current process the chlorine could possibly be bound to $\mathrm{CaO}$ during gasification. ${ }^{12}$ Because co-current moving bed gasifiers appear promising for the previously mentioned applications and as little pertinent study has been devoted recently to their operation, we shall discuss this type of reactor in more detail.

\section{THE CO-CURRENT MOVING BED GASIFIER}

Most of the early research and development on this gasifier type occurred around the period of the second world war and was aimed at a light, small reactor fuelling wood blocks for $20-100 \mathrm{~kW}$ car and lorry engines. An extensive survey of the different designs is presented by Schläpfer and Tobler. ${ }^{10}$ An improved design for a stationary solid waste gasifier has been developed in our laboratory (see Fig. 7). Based on this design (and a few modifications) demonstration pilot plants with capacities of 2,10 and $50 \mathrm{~kg} / \mathrm{h}$ have been erected and brought on stream. Typical operational data from these plants with wood blocks as the feedstock are included in Table 1. This type of gasifier will now be described. It is assumed that the process is maintained by a ventilator sucking the gas out of the gasifier. However, different modes of operation are possible.

\section{(a) Bunker}

The solid material is introduced at the top of the gasifier. It is not necessary to use complex sluices because a small amount of air leakage can be tolerated there. Normally filling will be discontinuous and then the bunker volume depends on the time betweeen successive fillings and the density of the waste. Due to heat transfer from the hotter lower zones of the reactor within the bunker, drying takes place. 


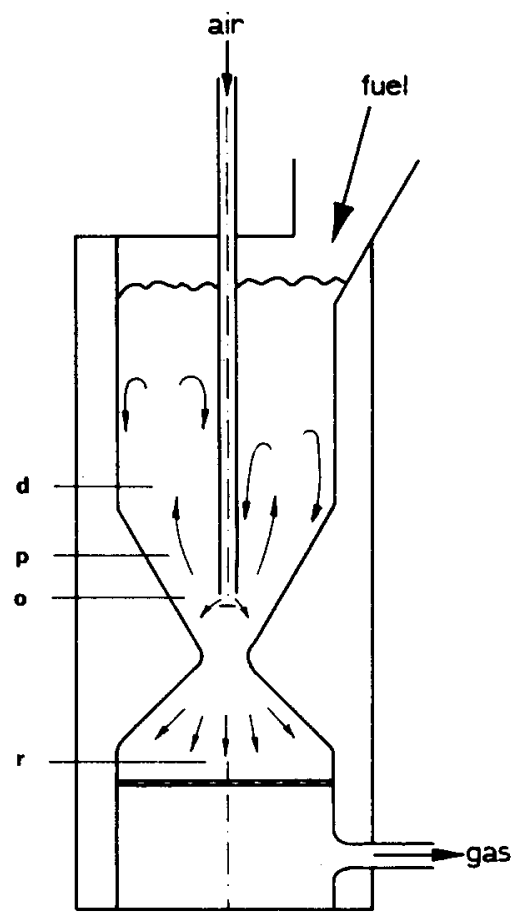

Fig. 7. Co-current gasifier. (d: drying zone; $p$ : pyrolysis zone; o: oxidation zone; $r$ : reduction zone.)

(b) Pyrolysis zone

In lower places the solid material starts pyrolysing at $250^{\circ} \mathrm{C}$, producing char, condensable and non-condensable gases. A typical product distribution for the pyrolysis of wood at $400^{\circ} \mathrm{C}$ is given in Table $2 .{ }^{13}$ The distribution depends primarily on the heating rate, temperature and particle size. Normally some consecutive tar conversion takes place, especially at low heating rates and for large particles. All the pyrolysis products move to the oxidation zone.

\section{(c) Oxidation zone}

Here air is introduced. The reactions with oxygen are highly exothermic and result in a sharp rise in temperature up to $1200-1600^{\circ} \mathrm{C}$. An important function of the oxidation zone, apart from heat generation, is to convert and oxidise all the condensable organic products from the pyrolysis zone. This is a direct result of the high temperatures prevailing. To avoid cold spots in the oxidation zone, where tar could pass uncracked, the air velocity and reactor geometry must be well chosen. To satisfy this aim, two methods are proposed: (i) reducing the cross-sectional area, commonly by means of a so-called throat and (ii) spreading the air inlet points at the wall of the gasifier over the whole cross-section (see Fig. 8) or using a central air inlet 
TABLE 2

PRODUCT DISTRIBUTION (BY WEIGHT) FOR THE PYROLYSIS OF WOOD AT $400^{\circ} \mathrm{C}$

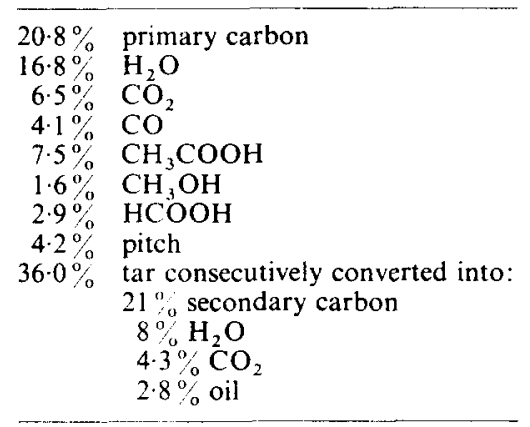

with a spray nozzle introduced from the top (see Fig. 9) or from the bottom (see Fig. 10). Although a throat can hinder the solid flows, no design has been developed that directly produces a tar-free gas without a throat. Combinations of a central air inlet with wall inlet points have been applied but Schläpfer and Tobler ${ }^{10}$ conclude that the residual tar production is not reduced further and that it is more difficult to control the amounts of air at all the introduction points.

The final design depends on the feedstock properties such as the heat of combustion, the rate of tar production, the bunker flow characteristics and the scale of operation. For the gasification of waste the central air inlet from the top is preferred because this inlet tube can also be used for stirring the bed. The products of the oxidation zone (hot gases and glowing charcoal) move downwards to the reduction zone.

\section{(d) Reduction zone}

In this zone the sensible heat of the gases and charcoal is absorbed in the
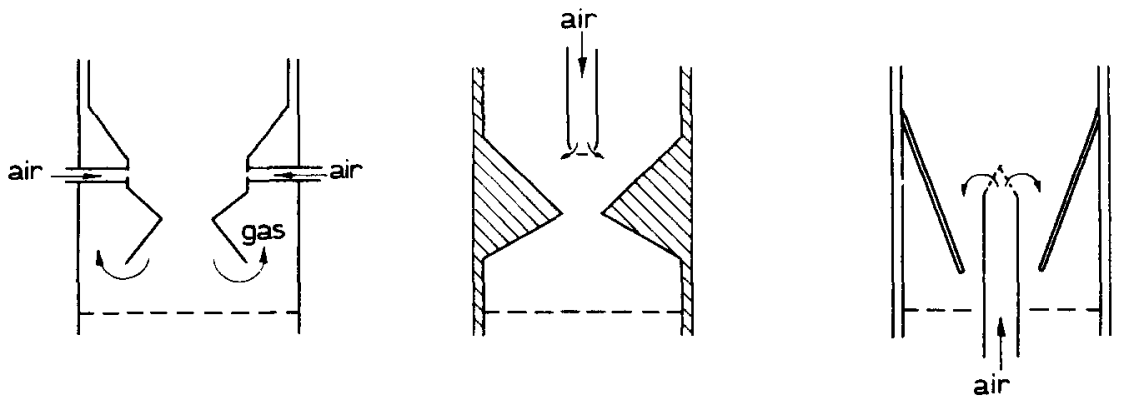

Figs. 8, 9 and 10. Oxidation zone with air inlet points positioned respectively, at the wall (Imbert), with central air inlets from the top and from the bottom. 
endothermic reactions between water, carbon dioxide and carbon in the charcoal. Consequently, a hydrogen- and carbon monoxide-containing fuel gas is produced.

From a model investigation ${ }^{12}$ it was concluded that near the oxidation zone, where the temperatures are still high, carbon is consumed in the outside layers of the particles only and hence they shrink. In the lower and cooler parts of the reduction zone, the carbon is consumed throughout the whole particles, thus lowering the density of the particle until it collapses due to mechanical forces. The ash, containing some carbon, should be removed occasionally. Whether a grid is necessary and how it should be designed depends on the amount of ash and its melting point. In the case of agricultural and forestry waste gasifications the amount of ash is often so small ( $<1 \%$ by weight of the feedstock) that operation without a grid is possible.

The product gas, which is practically free of tar but contains some dust or soot, leaves the reactor at $\pm 700^{\circ} \mathrm{C}$. After dust removal it is ready for use in modern equipment such as boilers and gas turbines and, after cooling, in internal combustion engines.

\section{APPLICATIONS OF THE CO-CURRENT MOVING BED GASIFICATION PROCESS}

\section{The gasification of agricultural and forestry waste in developing countries}

The development of rural areas in the Third World is highly dependent on the availability of decentralised energy supplies. In many cases the energy is generated with internal combustion engines powering tractors, water pumps, workshop machinery, electrical generators for local electricity supply or machinery to process agricultural products. It would be preferable to change from expensive, often imported, diesel oil or petrol to a gasification of agricultural and forestry waste in order to produce a fuel gas that can be used directly in engines. The following requirements should be fulfilled in order to be able to use gasification technology in rural areas:

the waste should be available without damaging the environment or agricultural system;

the equipment necessary for the gasification process should be constructed, or at least maintained, locally;

the process should be profitable for the owner(s);

the technology should be appropriate to the existing social and cultural systems and preferably benefit the poorest strata of society.

As an example, the gasification of maize cobs in an Ujamaa village in Tanzania will be discussed. ${ }^{12}$

In many villages maize is grown both as a cash crop and for local consumption. The locally eaten maize is cultivated on individual plots and milled locally in a maize mill which is often powered by a $20 \mathrm{~kW}$ engine. The cash crop maize grows, in the case of the Ujamaa villages, on communal fields of 40-200 ha. The communal fields 
produce $2500 \mathrm{~kg} / \mathrm{ha} / \mathrm{y}$ maize, which is shelled in the village by hand-picking and sold as grain. Consequently, $450 \mathrm{~kg} / \mathrm{ha} / \mathrm{y}$ maize cobs are produced and these are deposited on enormous heaps in the villages. Because of the high carbon-to-nitrogen ratio, it is inadequate as mulch fertiliser and, apart from some use as cattle feed for very dry periods, no alternative use is known or foreseen.

It has been estimated that the $20 \mathrm{~kW}$ mill engine will consume \pm 28 tpa maize cobs if gasification is used to power the mill and a mechanical sheller. This amount is readily available. For Ujamaa villages the mills can be owned communally and then the profit could be used to lower the price of milling and so raise the income of the people by about $10 \%$. Alternatively, from the profit, communal facilities can be purchased (up to the maximum value of $20.000 \mathrm{TSh} / \mathrm{y}=2750 \mathrm{US} \$ / \mathrm{y}$ ). As maize mills are already familiar, no social or cultural changes are to be expected. The required capacities $( \pm 30 \mathrm{~kg} / \mathrm{h})$ are no different from those tested in our laboratory where maize cobs are also gasified. An appropriate design is proposed for this purpose (see Fig. 11). In the near future these gasification processes will be tested out in Tanzania under local circumstances.

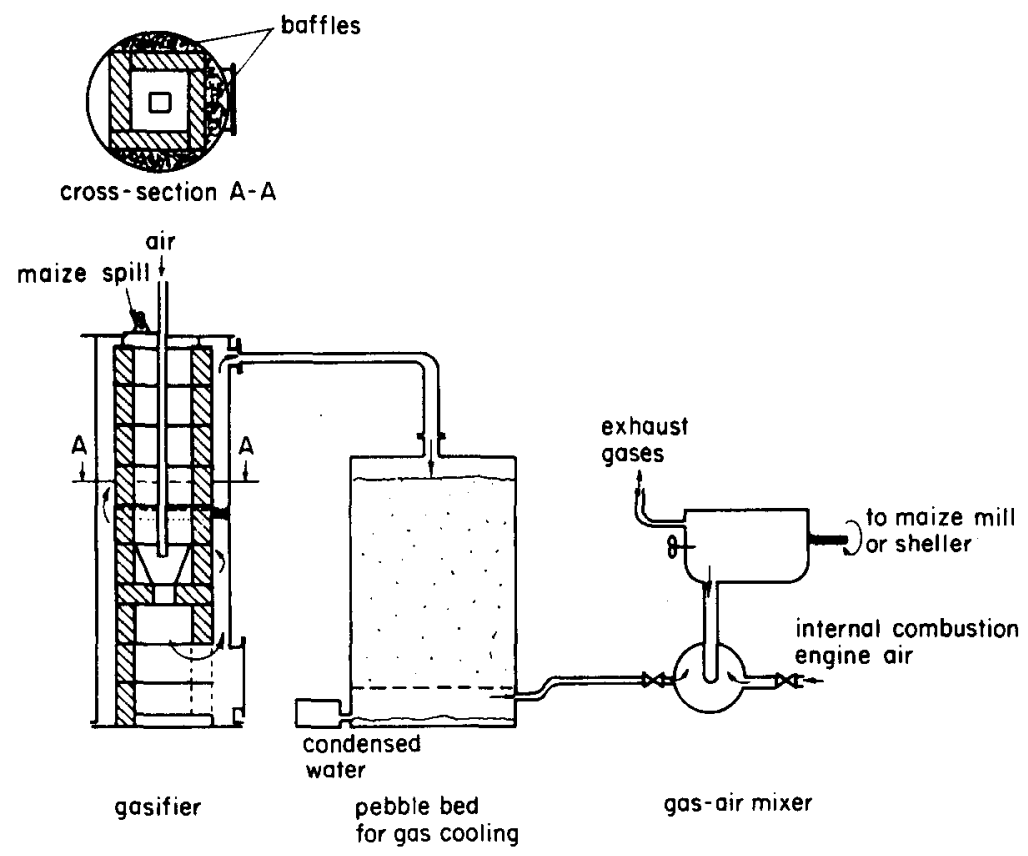

Fig. 11. Gasification process appropriate for maize milling in Tanzania.

The gasification of domestic waste

In the developed world, domestic waste is so abundant that several processes have been developed or are under development for its conversion. These processes should 
be optimised in order to reduce environmental pollution and with respect to economics. In many cases nowadays the refuse is incinerated, sometimes after separating constituents with a high specific value such as iron. The environmental control of this incineration, especially with respect to dust particles, smoke, hydrochloric acid and heavy metals, is costly. Recovery of the energy is hardly renumerative because of costly corrosion prevention measures necessary for boiler protection. To cope with some of these problems gasification processes have been proposed and brought into operation. ${ }^{6.14}$ These processes involve counter-current moving bed reactors with liquid ash removal. Co-current operation could be advantageous, however, because of the tar-free gas production. From this product gas, hydrochloric acid and hydrogen sulphide, fly ash and other noxious components can be removed by well known wet or dry processes. Prior to incineration by this means a clean process can be obtained without the more expensive cleaning of the much larger quantities of flue gas. It seems likely that the acetous gases can be absorbed in dolomite or calcium oxide during gasification so that the gas can be used without further treatment. This clean gas could then be used in a cheap, perhaps already existing, gas-fired boiler or gas turbine (see Fig. 12). The

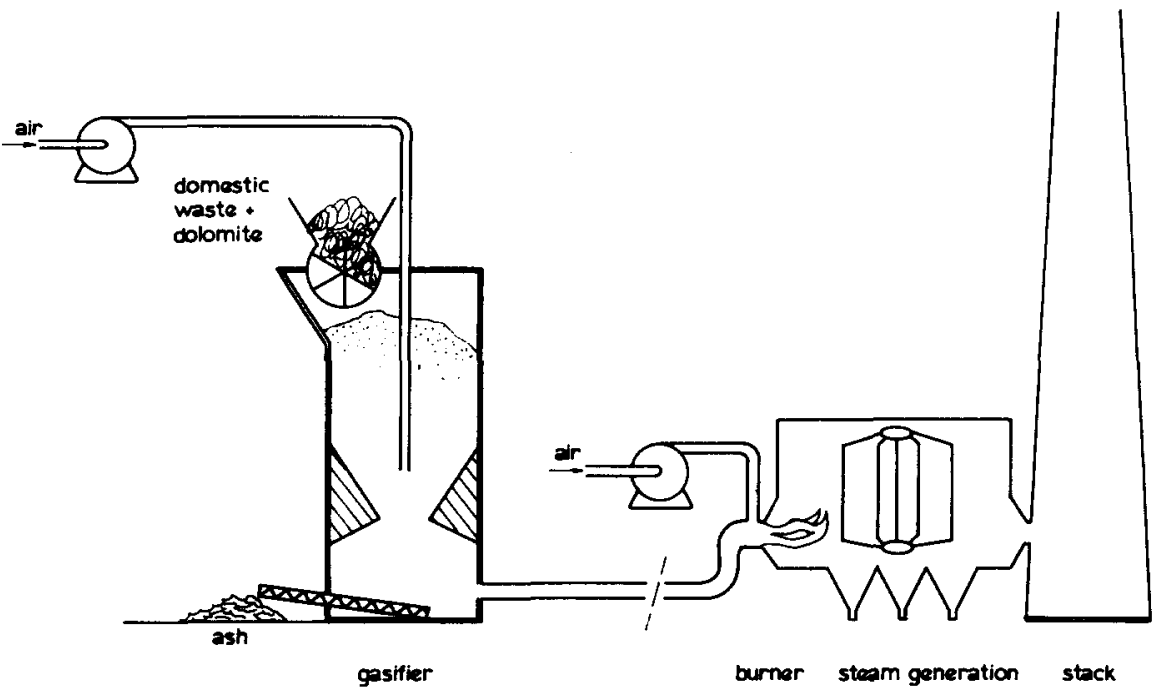

Fig. 12. Gasification of domestic waste with a co-current gasifier.

same holds, of course, for all the organic refuse materials but domestic waste is the biggest problem. Consequently, the processing of refuse by gasification in a cocurrent moving bed reactor will produce less pollution and might even, perhaps, be more economic. Experiments are being carried out to test these possibilities for (domestic) waste gasification. 


\section{REFERENCES}

1. J. A. Hassan, The gas market and the coal industry in the Lothians in the 19th century, Industrial Archaeology, 11(4), (1977), pp. 49-74.

2. F. FisCHER, and J. GwOSDZ, Kraftgas. Theorie und Praxis der Vergasung fester Brennstoffe, Otto Spamer, Leipzig, 1921.

3. J. MEunier, V'ergasung fester Brennstoffe und oxydatieve Unwandlung von Kohlenwasserstoffen, Verlag Chemie GmbH, Weinheim, 1962.

4. J. Falbe, Chemierohstoffe aus Kohle, G. Thieme Verlag, Stuttgart, 1977.

5. K. LitTlewOOD, Gasification: Theory and application, Prog. Energy Comb. Sci, 3, (1977), pp. 35-71.

6. Conversion of Refuse to Energy. First International Conference, Montreux, Switzerland, 3-5 November 1975 ,

7. P. F. H. RUDOLPH, Energiespectrum (1977), pp. 311-21.

8. M. R. TEK et al., Evaluation of coal concersion processes to provide clean fuels, Part II, EPRI 206-0-0 NTIS PB $234203,1974$.

9. S. B. ALPERT et al., Pyrolysis of solid waste: A technical and economic assessment, NTIS PB 218231, 1972.

10. P. SCHLÄPFER and J. TOBLER, Theoretische und praktische Untersuchungen über den Betrieb von Motorfahrzeuge mit Holzgas, Bern, 1937.

11. X. SoEHNER, Power production from tropical vegetable waste, Engineering (1937), pp. 569-71, 599-600.

12. M. J. Groeneveld, Ph.D. thesis, Twente University, The Netherlands, to be published.

13. P. Klason, Versuch einer Theorie der Trockendestillation von Holz, Journalf, prakt. Chemie, 90, (1914), p. 413.

14. Abfallwirtschaftsseminar Thermisches Verfahren der Abfallbeseitigung, 26-30/6/1978, Berlin, Müll und Abfall, 10(9), (1978), pp. 291-2. 